\title{
UMA EDUCAÇÃO NADA SENTIMENTAL: A \\ PREPARAÇÃO DE GAROTOS WAKASHU
}

\section{Madalena N. Hashimoto Cordaro ${ }^{1}$}

Resumo: A questão das técnicas de ensino do caminho dos garotos profissionais é enfocada através da tradução de um pequeno manual de Tsukioka Settei composto de textos e imagens. Utilizando a retórica da paródia mitate e tomando por objeto o teor de obras confucionistas destinadas à formatação dos modos femininos, o pintor dedica algumas composições tematizando a construção do corpo sexual dos garotos bem no método hilário dos citadinos.

Palavras-chaves: período Edo; pintura erótica shunga; Tsukioka Settei; garotos wakashu; manual de educação sexual.

Abstract: The question of professional boys way teaching techniques is focused through the translation of a Tsukioka Settei small manual which contains texts and images. Using the mitate rethorics of parody and taking for object the Confucian works contents aimed at women ways formats, the painter dedicates some compositions centered in the boys sexual body construction theme in townsmen hilarious methods.

Keywords: Edo period; shunga erotic painting; Tsukioka Settei; wakashu boys; sexual education manual.

Talvez existam pessoas que afirmem haver áreas em que não se necessite do ensino e de suas técnicas de repetição e memorização, em que o aprendizado se dê de modo espontâneo, prazeroso e fácil; entretanto, buscar-se-á demonstrar no presente estudo que para tudo há um método. No período Edo, são notórios nas artes literárias e pictóricas os caminhos da fruição dos sentidos e do caráter lúdico das apreciações de fundo estético. Se flores e pássaros, montanhas e rios, locais

1. Professora Adjunta da área de Língua e Literatura Japonesa do Departamento de Letras Orientais da FFLCH-USP. 
famosos ("travesseiros de poemas") são objetos de escrutínio pormenorizado, também o são os modos do amor físico, numa retomada do cultivo amador do irogonomi de antanho, do período Heian. Citadinos retomam, em aparente paródia vulgar, tópicas célebres da mais pura tradição clássica da poesia e constroem um sistema de humor sofisticado, ao mesmo tempo fascinante em sua tensão de seriedade e jocosidade.

A obra a ser enfocada trata da educação de garotos, relatada em todos os seus passos, progressivos como devem ser, para sua profissionalização mais efetiva. Por garotos wakashu entendam-se como diz o nome, a classe dos jovens; por garotos profissionais, entendam-se os kagema, em várias versões de ideogramas como traz o eloquente verbete de Komatsu²: 陰間 - 影間 - 艶野郎 - 艶郎 - 野郎 - 街艶郎.

De Tsukioka Settei, o pesquisador Hanasaki fez a leitura da obra Onna Daigaku Takara-beki 女大学宝開 (Abertura de Tesouros de Ensinamentos para Mulheres), uma paródia dos sisudos ensinamentos escritos pelo confucionista Kaibara Ekiken (Ekken) 貝原益軒(1630-1714), Onna Daigaku Takara-bako 女大学 宝箱 (Caixa de Tesouros de Ensinamento para Mulheres), extensamente reeditada entre os anos de 1716 a 1736, contendo inclusive um trecho a ele atribuído, no entanto póstumo. Hayakawa Monta, entretanto, faz ler o título como: Onna Daigaku Takara-hako 女大学宝開 (Abertura [Caixa] de Tesouros de Ensinamentos para Mulheres), o que mostra a ambiguidade linguística do período Edo e sua libertária utilização, não raro hilária. A obra de Tsukioka Settei foi considerada um marco na "educação e formação" dos garotos kagema, e foi reeditada até depois da Segunda Guerra Mundial, porém somente com o texto. Hanasaki Kazuo, pois, tem o mérito de publicar a imagem e o texto, transcrito, que aqui se tentará traduzir ${ }^{3}$ Embora extensa, acredita-se ser crucial no desenvolvimento do conceito do amor por garotos vigente no período Edo, por seu caráter abrangente e concreto.

Como lembra Hayakawa, o pintor Tsukioka Settei era de Osaka, sendo suas representações bastante particulares quando comparadas às de Edo, especialmente nas expressões faciais. Sobre suas pinturas circulava uma aura de que tinha o poder de proteger dos incêndios, o que lhe proporcionava muitas encomendas e respeito.

As imagens que se seguem trazem a imagem de cada página do livro, em formato horizontal pequeno, com a transcrição do texto e notas de Hanasaki abaixo e entre parêntesis, e o texto em português com notas da tradutora entre chaves. A tradução tenta seguir o texto de cada página, tarefa quase completamente bem sucedida (atente-se para a ordem sintática diversa da língua japonesa: sujeito objetos - verbo).

2. Leia-se Komatsu Keibun, Iro-no Jiten, 2000, p. 169-170.

3. In Edo-no Kagema-jaya, 2002, p. 75-99. Hanasaki não traz, entretanto, os textos inseridos, os quais, quando encontrados alhures, encontram-se também traduzidos. 


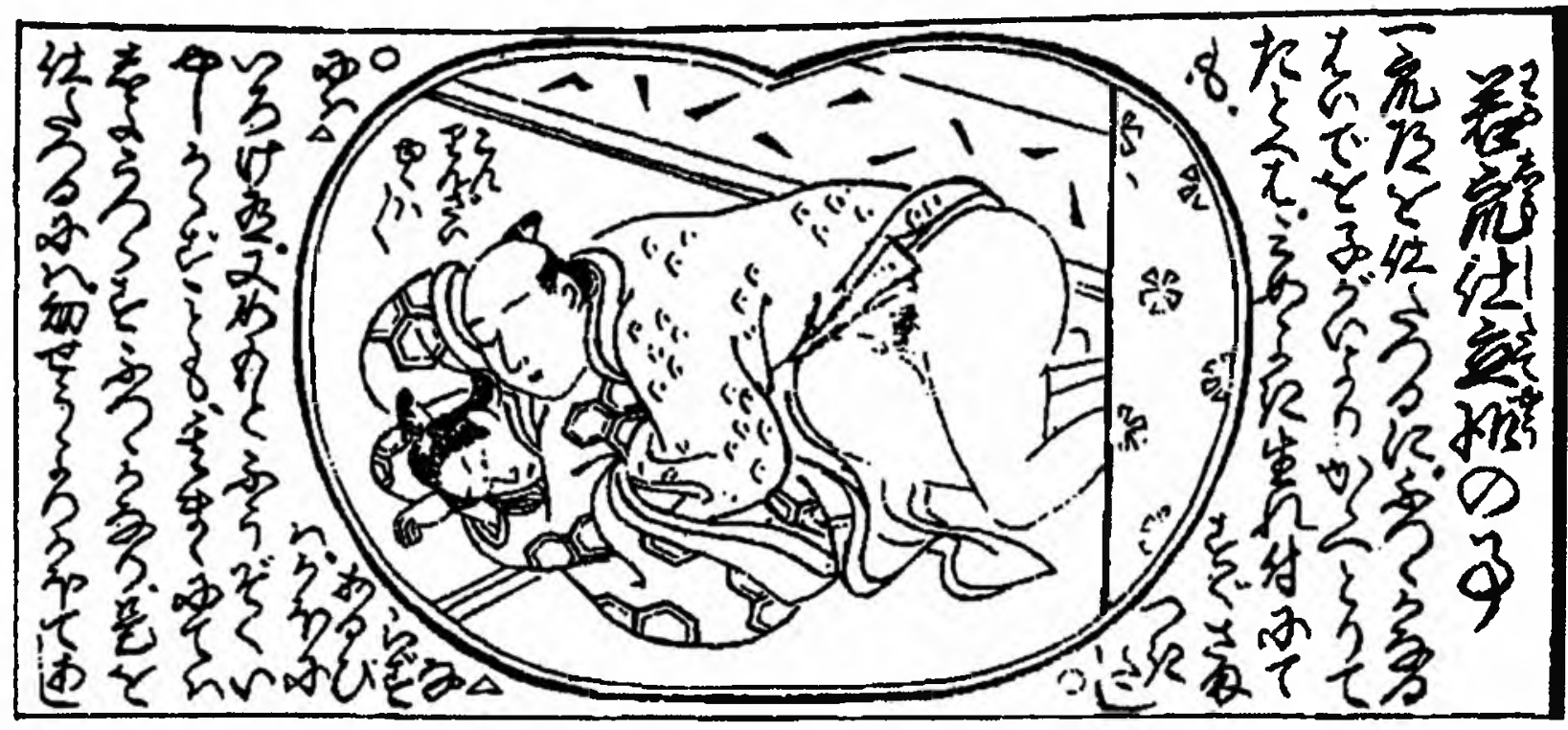

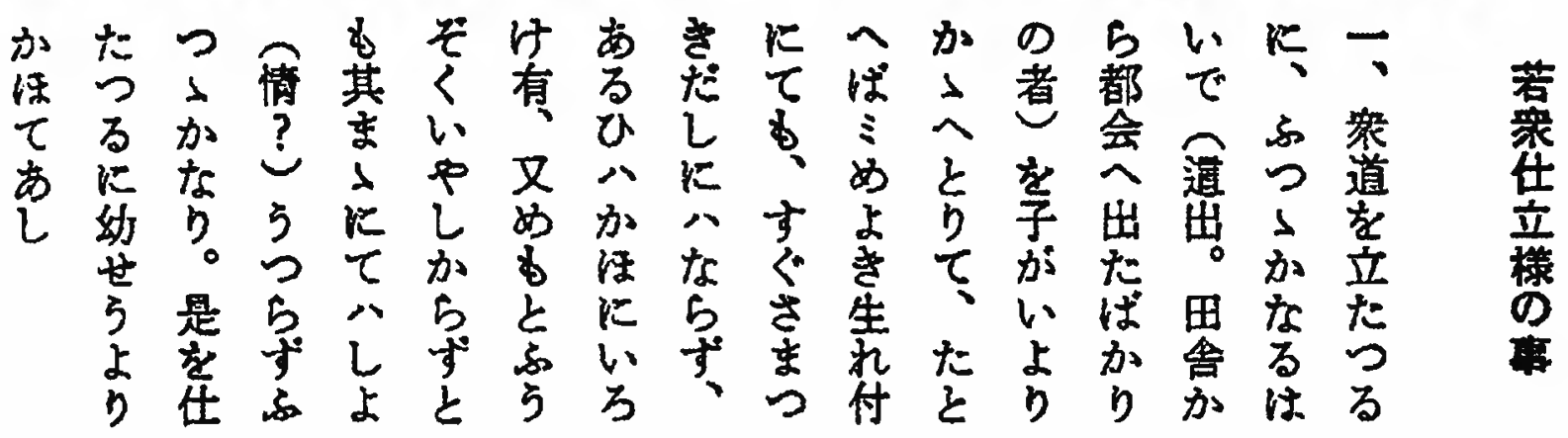

\section{Sobre os modos de se preparar garotos}

1. Para fazer prosperar um garoto, deve-se apanhar e carregar um menino próximo, como aquele recém-aparecido (recém-chegado do interior para a grande cidade), de corpo inquieto, e, por exemplo, mesmo que suas feições sejam boas de nascença, elas podem não se tornar logo protuberantes; ou alguém que tenha sensualidade no rosto; ou ainda alguém cuja expressão nos olhos não cause reprimendas em suas maneiras e, dessa forma, que não contagie o sentimento (?) e se inquiete. Para preparar esse tipo desde a infância, faces, mãos e pés (...)

Texto inserido:

"Kon rinzai yuku wa yuku wa"

「こんりんざいゆくはへヘヘ」

"Ah, vou até o fim do mundo, vou gozar, vou gozar!" 


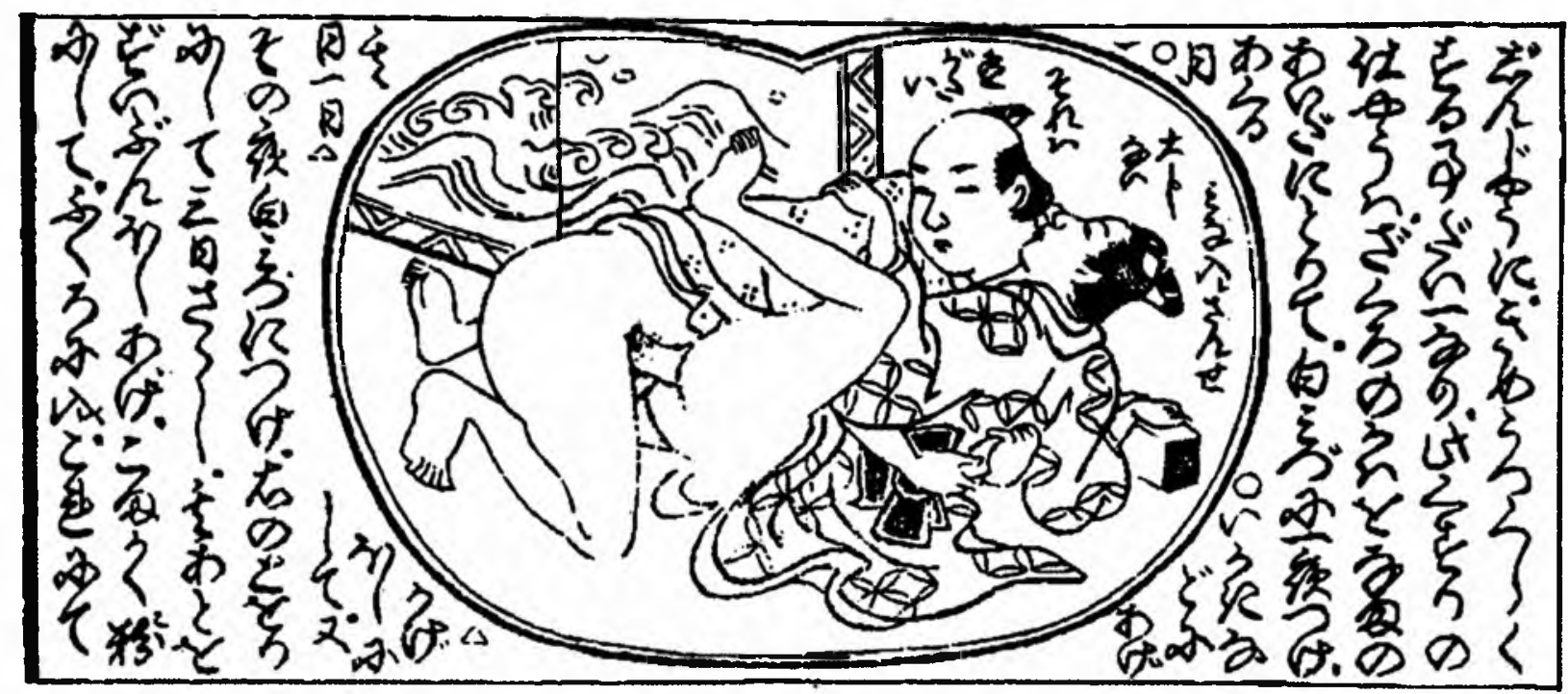

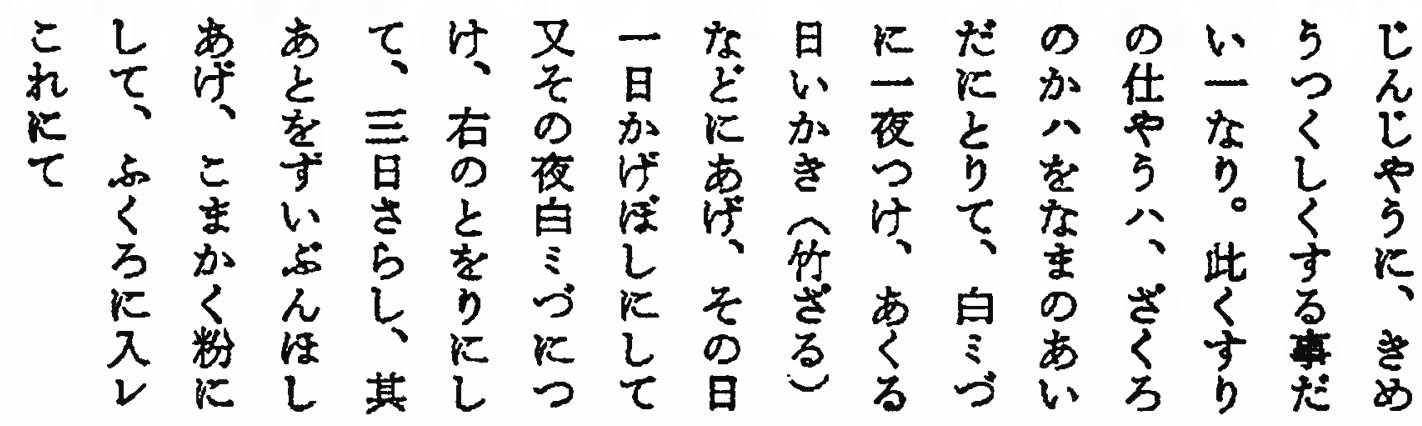

(...) normalmente, é acima de tudo necessário tornar bela a sua pele. Para fazer este remédio, deve-se pegar uma romã, tomar a casca ainda verde e deixar de molho na água durante uma noite; no dia seguinte, deixá-la exposta sobre um tubo de bambu; no outro dia, deixá-la secar na sombra e novamente nesta noite deixá-la de molho na água; pegar a parte direita, expô-la ao sol durante 3 dias e deixá-la secar completamente o resto; transformar tudo cuidadosamente em pó e colocar num saquinho; e se nessa substância (...) 


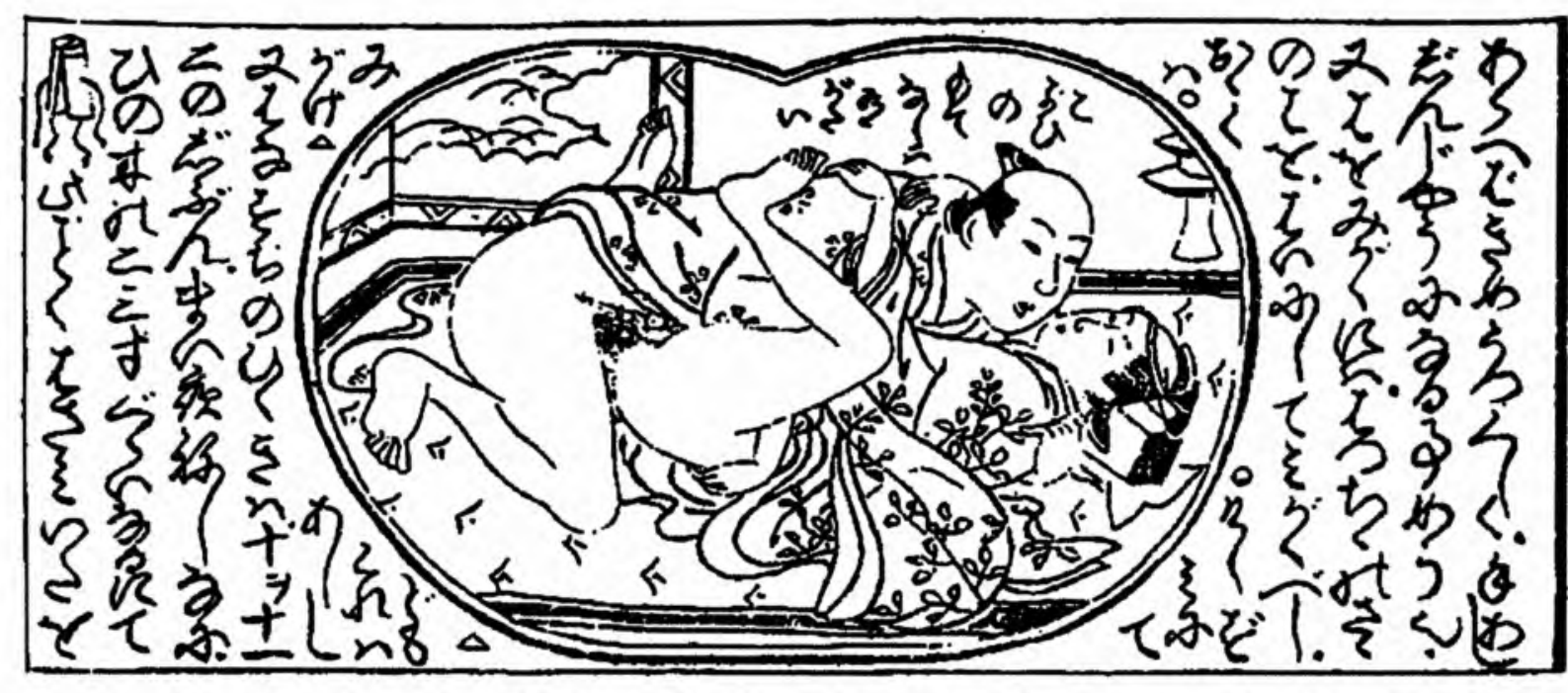

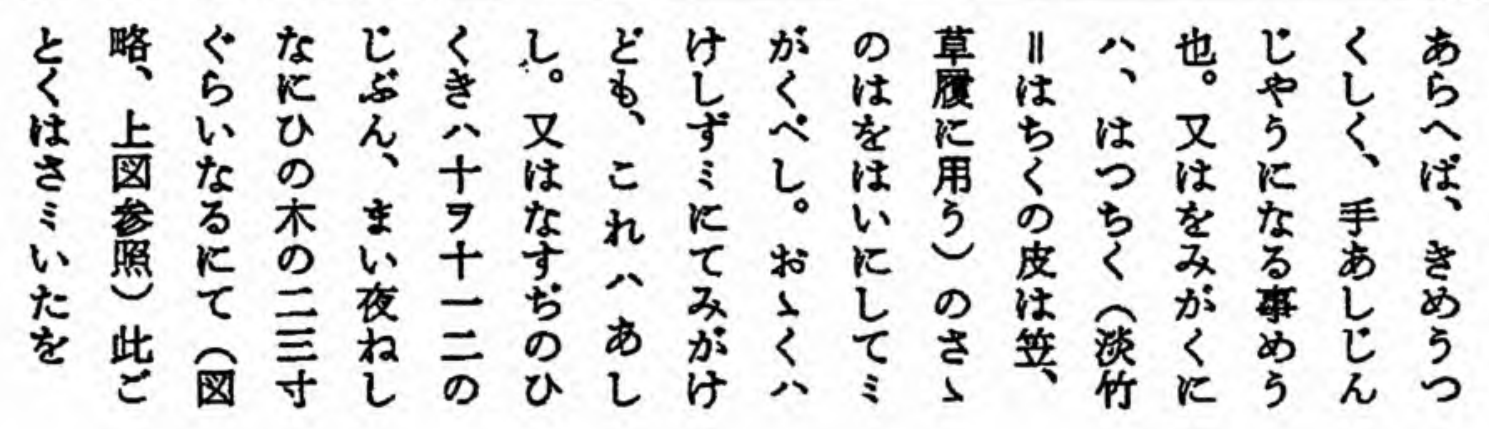

(...) for lavada, a pele fica bonita, as mãos e os pés normalmente ficam excelentes. Por outro lado, para escovar os dentes, deve-se fazê-lo utilizando a folha do bambu anão hachiku (utilizada também para fazer chapéus de chuva e sandálias de dedo de palha, zôri) que é transformada num copinho. Se escovar os dentes com uma escova que retenha muita água, isto é ruim. Ainda, o tempo de ficar esfregando as cerdas deve estar entre 10 a 11 ou 12 vezes; todas as noites, bem antes de ir se deitar, num cipreste hinoki de aproximados $70 \mathrm{~cm}$, dessa forma [desenho acima] (abrevia-se o desenho, veja-se acima) as mangas presas numa prancha de madeira (...)

Texto inserido:

"Koyoi-no me de nashi wa arigatai"

「こよいのめてなしは有がたい」

"Agradeço se ficar assim deste jeitinho...! 


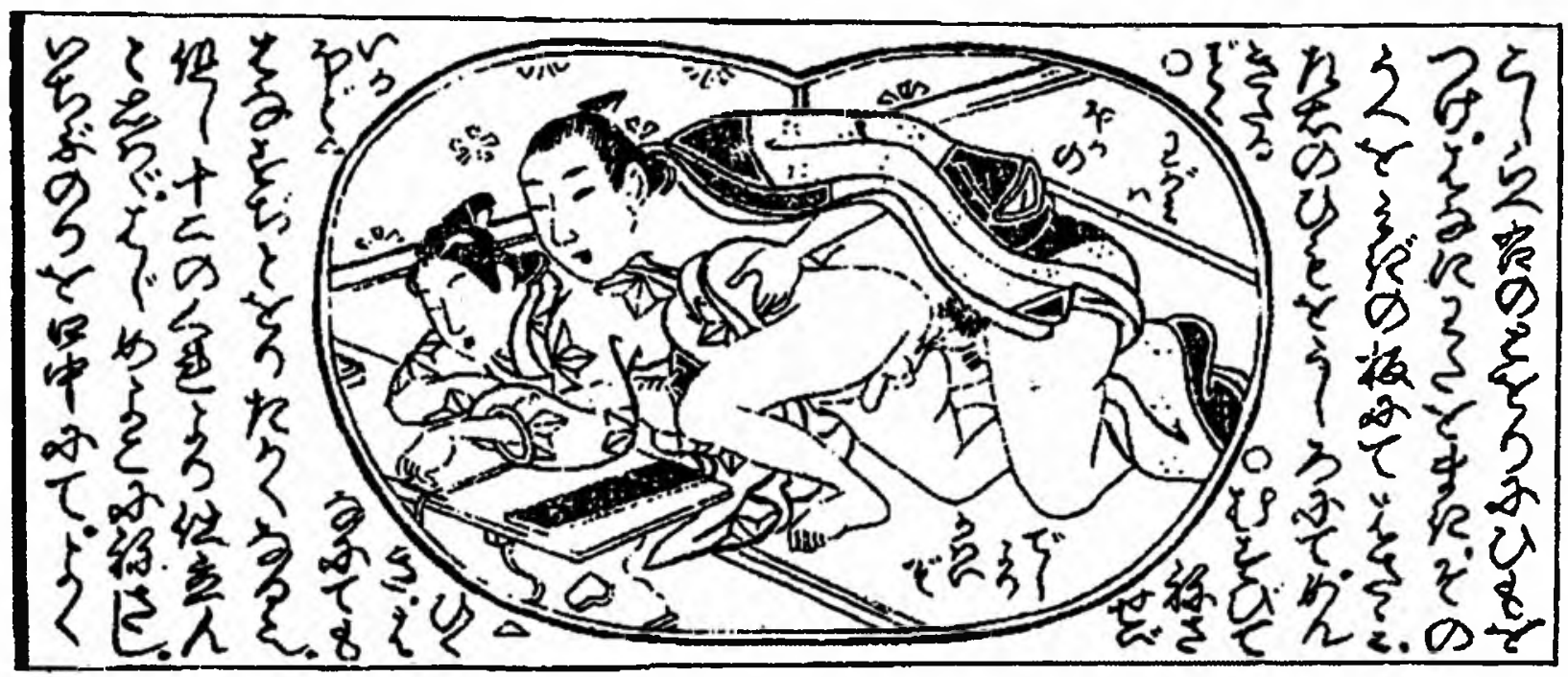

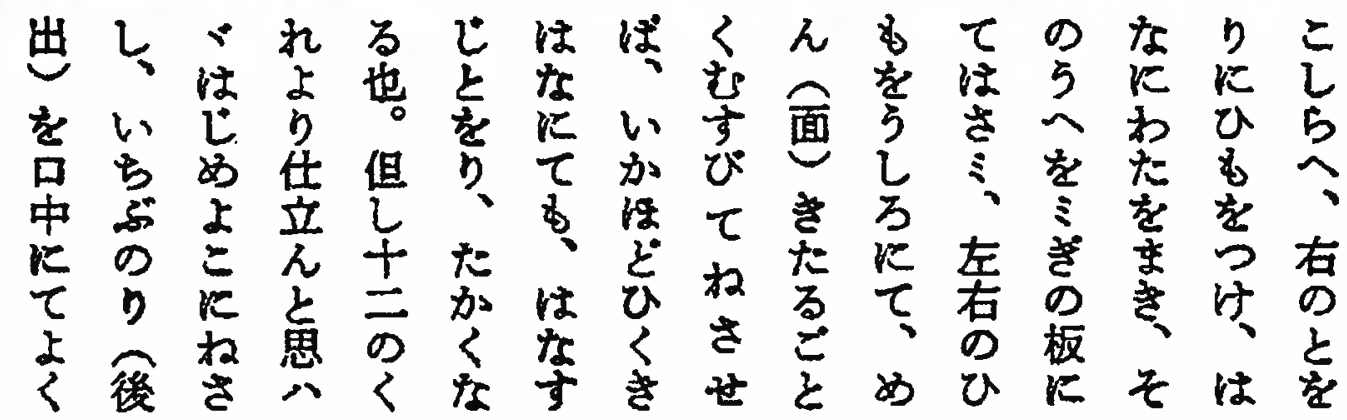

(...) devem ser confeccionadas: coloque o cordão no portão da direita; enrole as flores de algodão e a parte superior delas prenda na madeira da direita; coloque o cordão da direita e da esquerda para trás; amarre a parte que afluiu à superfície (máscara) e deixe repousar; por mais baixa que seja a flor, a passagem dos veios ficam altas. Entretanto, se for querer preparar a partir de mais de 12 , no início deve fazer deitar de lado, enfiar ichibu-nori dentro da boca e deixar bem (...)

Texto inserido:

"Wagami (sonata) wa hoka-no deshi yori kawaii zo" 「わがみ（そなた）はほかの弟子よりかはいいぞ」

"A sua pessoa é muito mais lindinha que os outros maninhos aprendizes, viu?" 


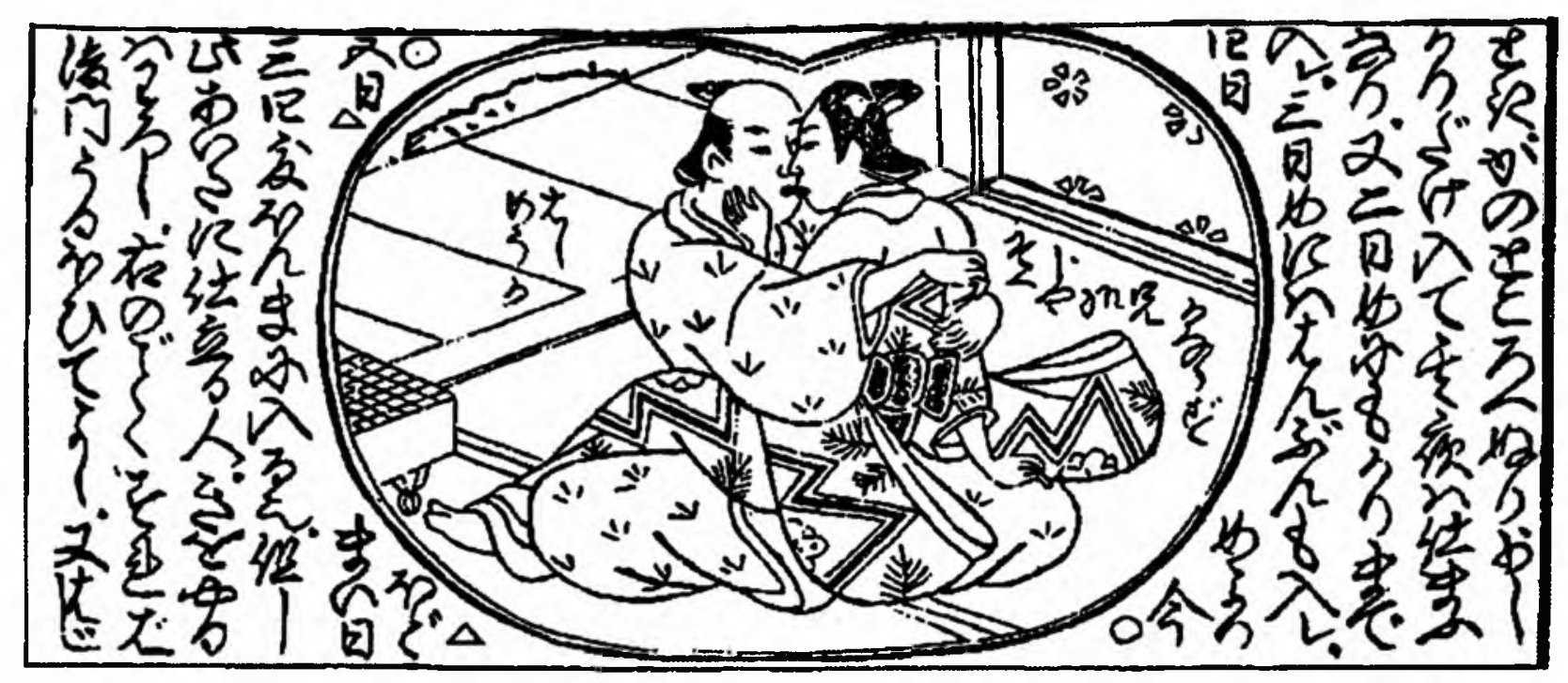

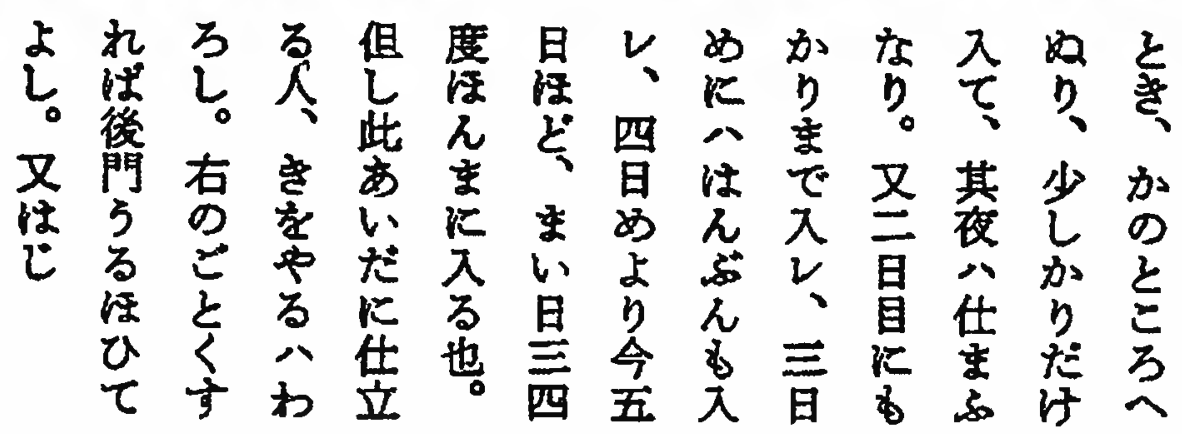

(...) derreter; passar em outros lugares, deixar entrar apenas um pouco do ganso selvagem; nessa noite será o término, já chega. De novo, no $2^{\circ}$ dia também entrar até o ganso selvagem [a glande]; no $3^{\circ}$ dia entrar até a metade; a partir do $4^{\circ}$ dia, por 5 dias, todos os dias entrar com tudo por 3 ou 4 vezes. Entretanto, nesse intervalo de tempo, a pessoa que prepara, é inapropriado que ela se deixe abandonar completamente [que goze]. Se fizer como se mostra à direita, tudo bem se umedecer o Portal de Trás. Ou então, (...) 


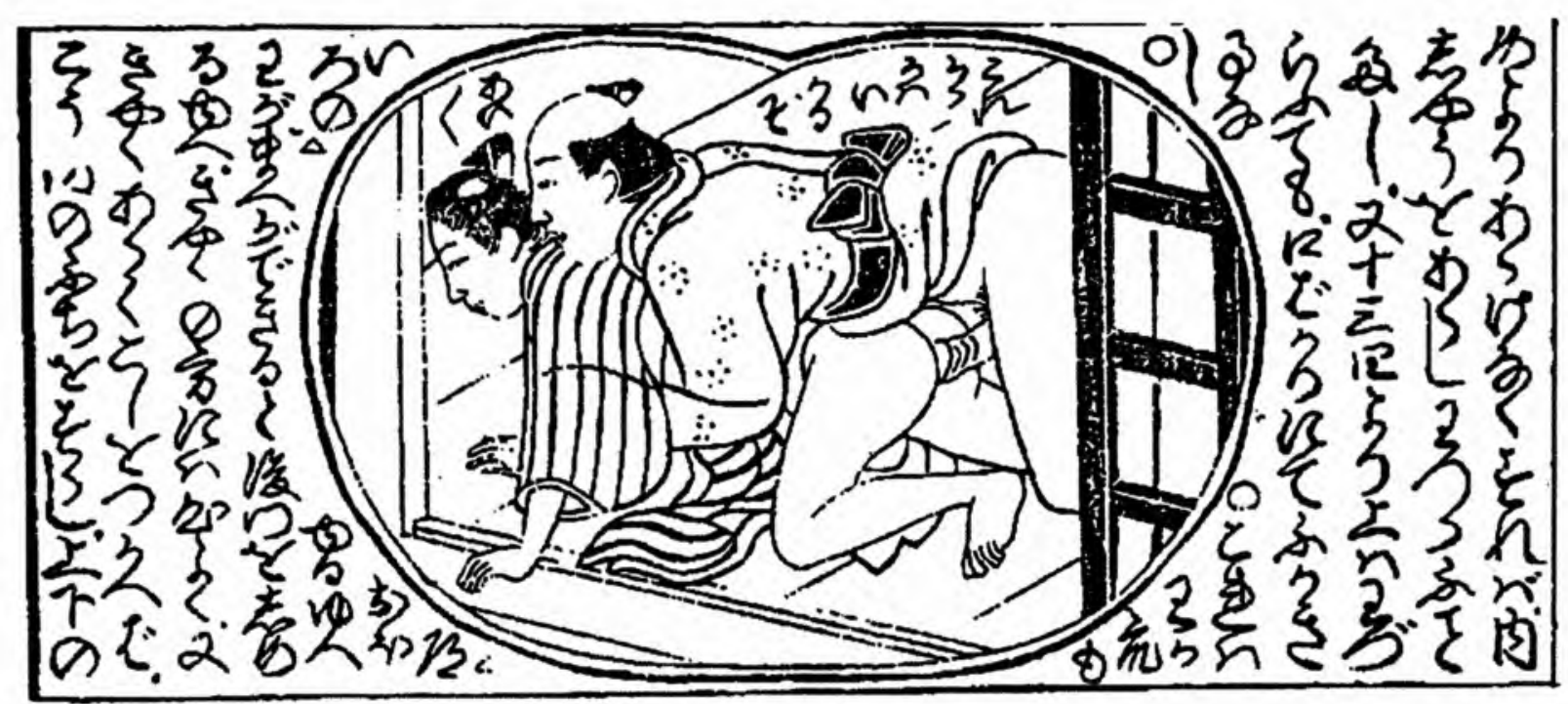

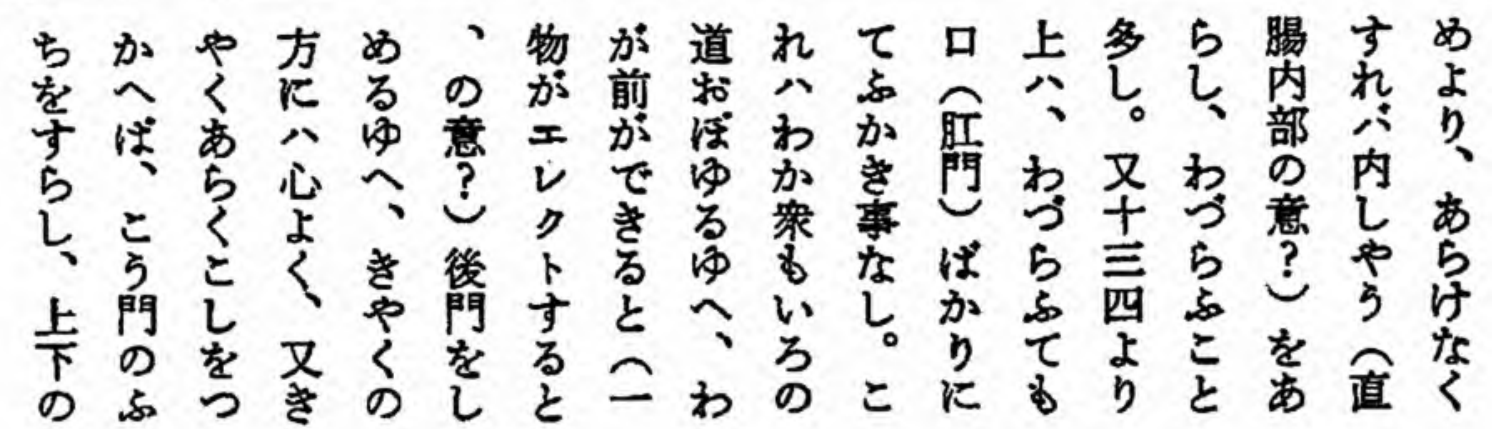

(...) se for violento desde o início, vai devastar o cano interno (sentido de parte interna do reto?) e é frequente que acabem sofrendo. Por outro lado, quanto aos maiores a partir de 13,14, mesmo que o devastem, não ocorre aprofundar somente na boca [Portal Anal]. Quanto a isso, os garotos também aprendem o caminho do sexo e, além disso, quando a sua propriedade da frente já consegue agir (sentido de conseguirem ereção do pênis?), além de trancarem o Portal de Trás, transferem seu coração para o cliente; ou então se os clientes usarem seus quadris de modo violento, modificam-se as bordas do Portal Anal; e de cima e de baixo (...) 


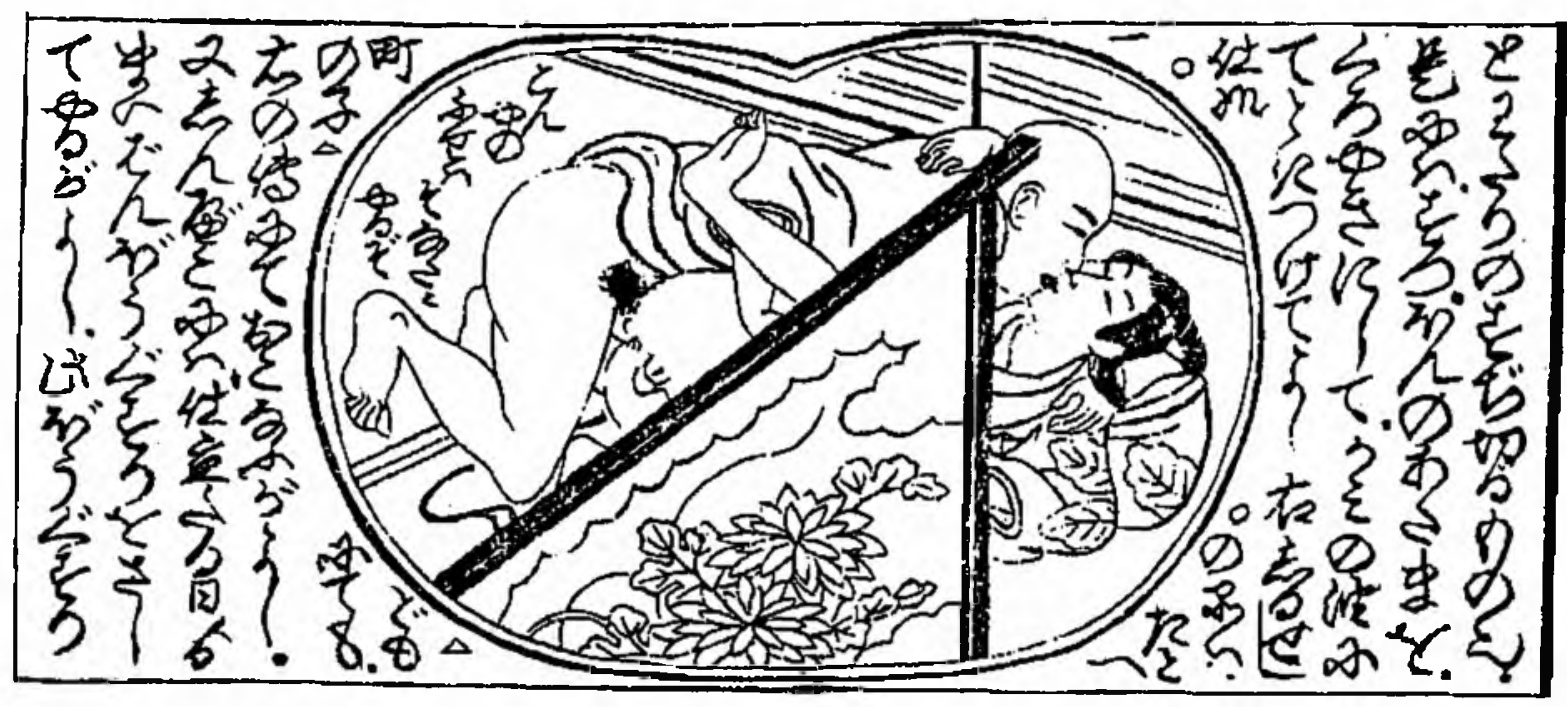

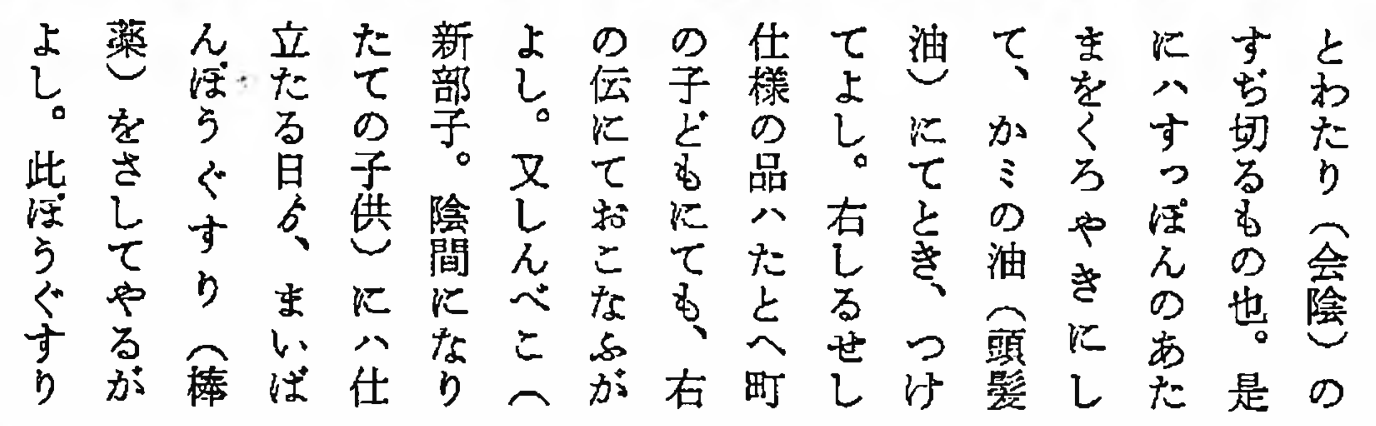

(...) acabam por cortar as veias da travessia (o períneo). Nisso, faz-se um grelhado bem passado da cabeça da tartaruga e é bom que se deixe exposto para diluir no óleo do cabelo (óleo do cabelo da cabeça). A mercadoria que à esquerda se mostra a forma de preparar, por exemplo, mesmo se for uma criança das cidades, é bom que se realize como transmitido à direita. Ou então, quanto a um menino novo no ramo (uma criança que acabou de se tornar kagema), no dia em que se for prepará-lo, é bom que todas as noites se lhe proporcione o medicamento da vara. Este medicamento da vara, (...) 


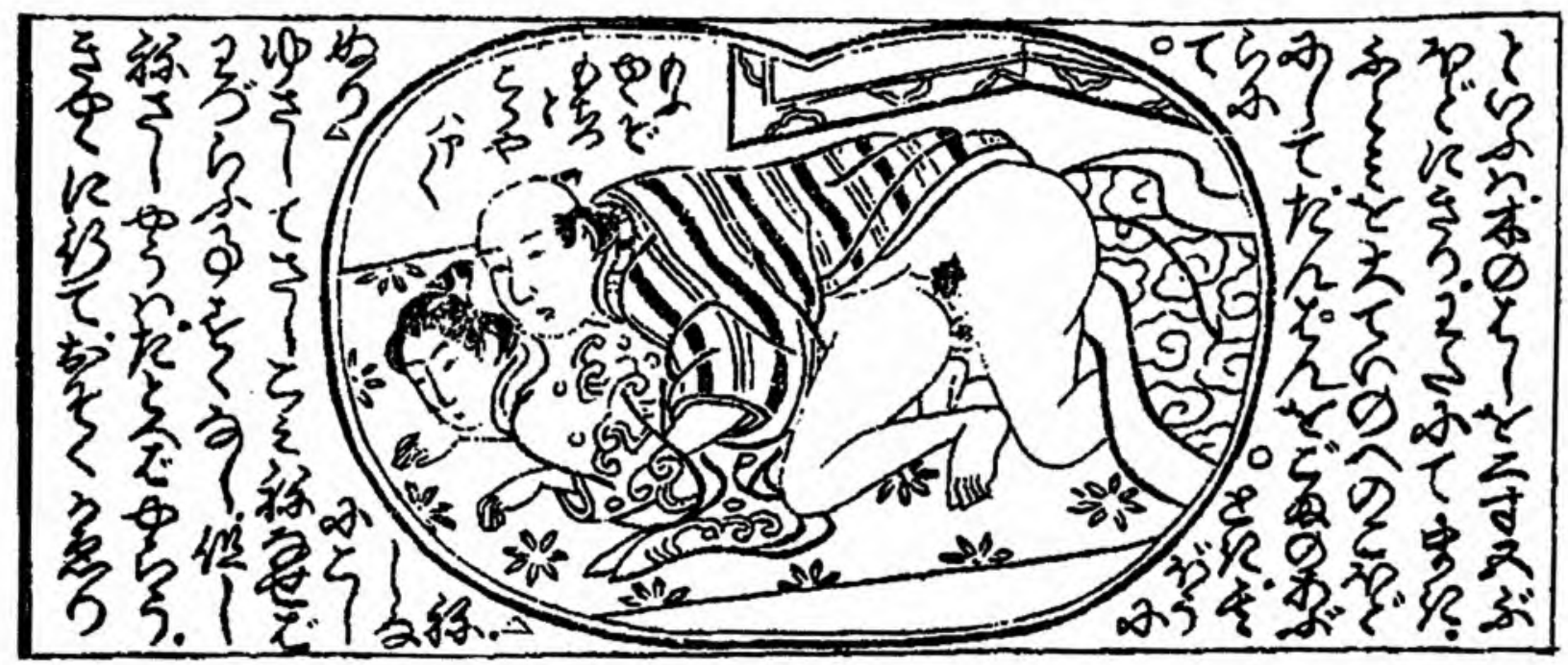

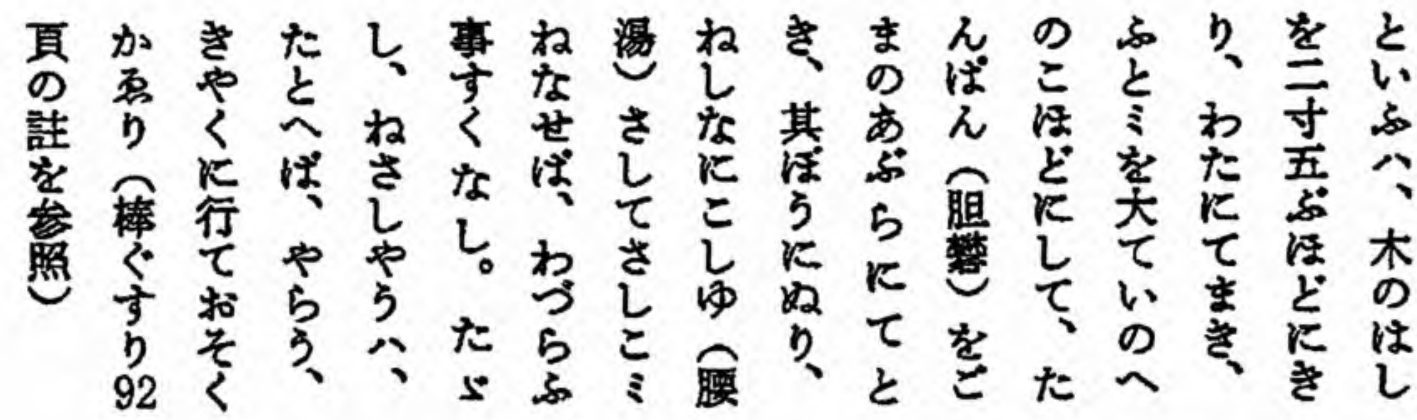

(...) como é chamado, [consiste em:] cortar a ponta de uma árvore em 5 pedaços de mais ou menos $6 \mathrm{~cm}$.; enrolar num algodão; fazer a grossura relativa da grandeza de um pinto; diluir azul vitríolo no óleo de gergelim e aplicar nesta vara; bem antes de dormir aplicar o líquido nos quadris (banho de quadris) e deixar assim enquanto dorme; é raro que impinja sofrimento. Entretanto, o modo de deixar aplicado enquanto se dorme, por exemplo, se forem já maiores de idade [yarô やらう], eles vão ao cliente e voltam tarde (...) 


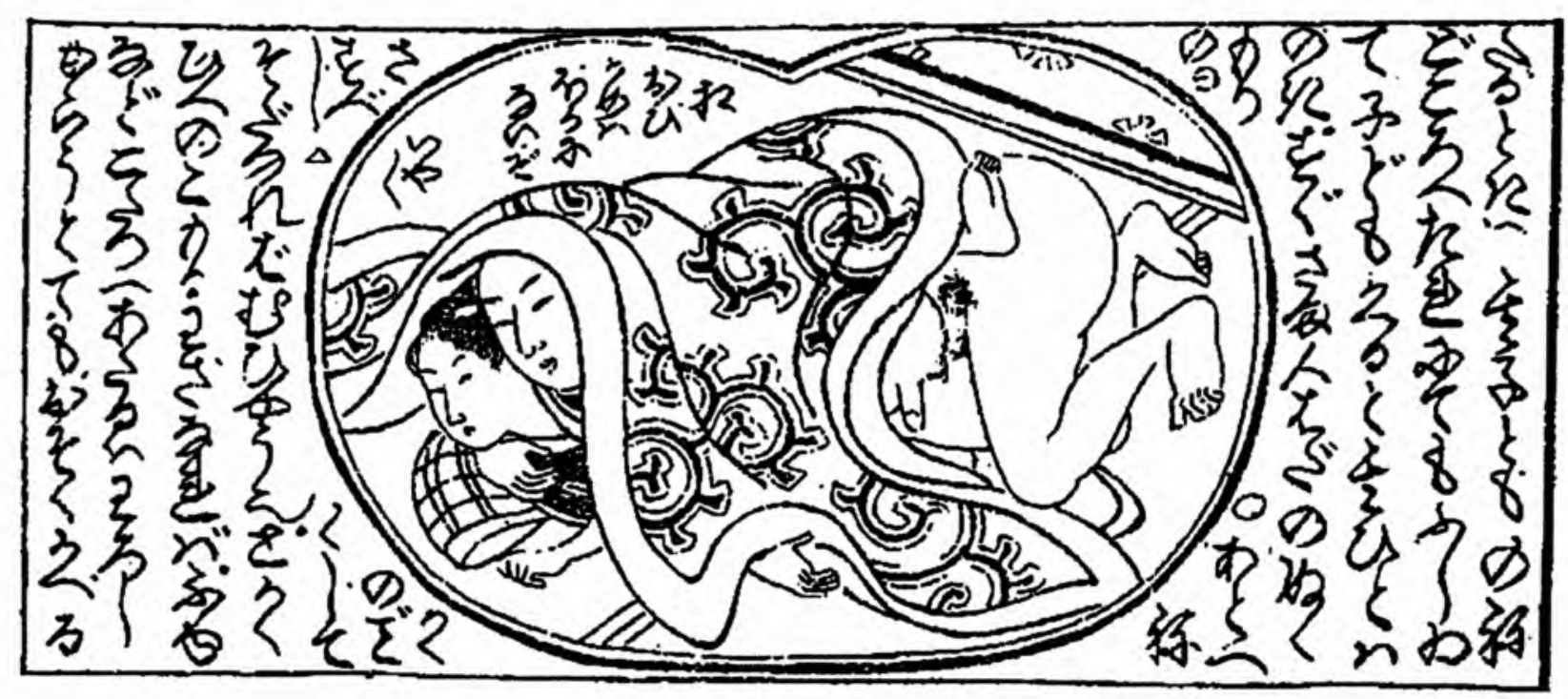

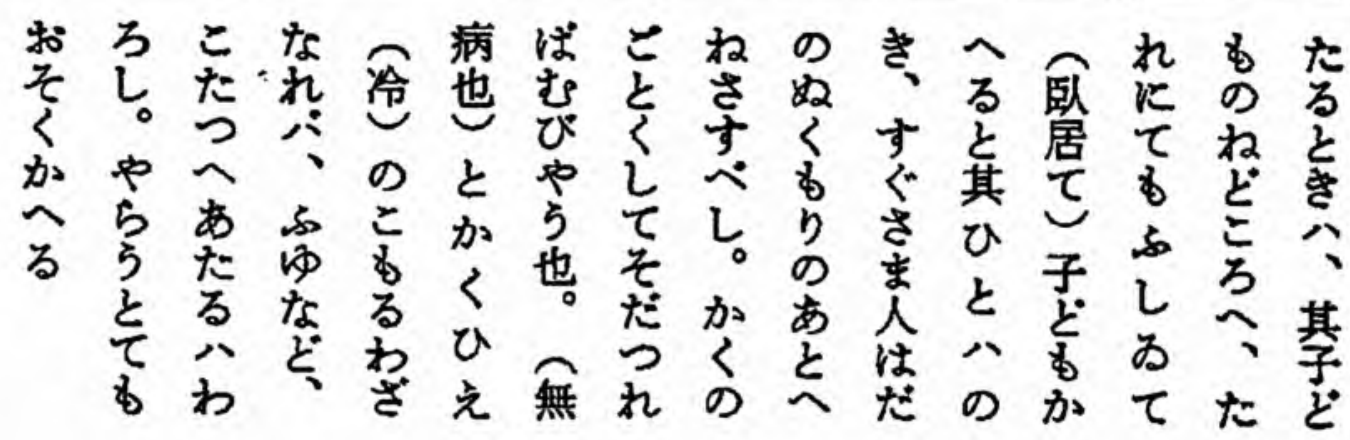

(...) são suficientes e nessa fase qualquer um pode se imiscuir no quarto de dormir da criança. E, se puder comprá-la, essa pessoa ficaria de lado e logo se deveria fazê-la dormir no lado de trás, com a quentura de sua pele. Se educá-la fazendo dessa forma, ela não adoecerá e se, por acaso, ela tiver de ficar confinada por ter se resfriado, é inapropriado que, no inverno, ela se exponha ao calor sob a mesinha [kotatsu こた]. Quando o mais velho volta muito tarde (...) 


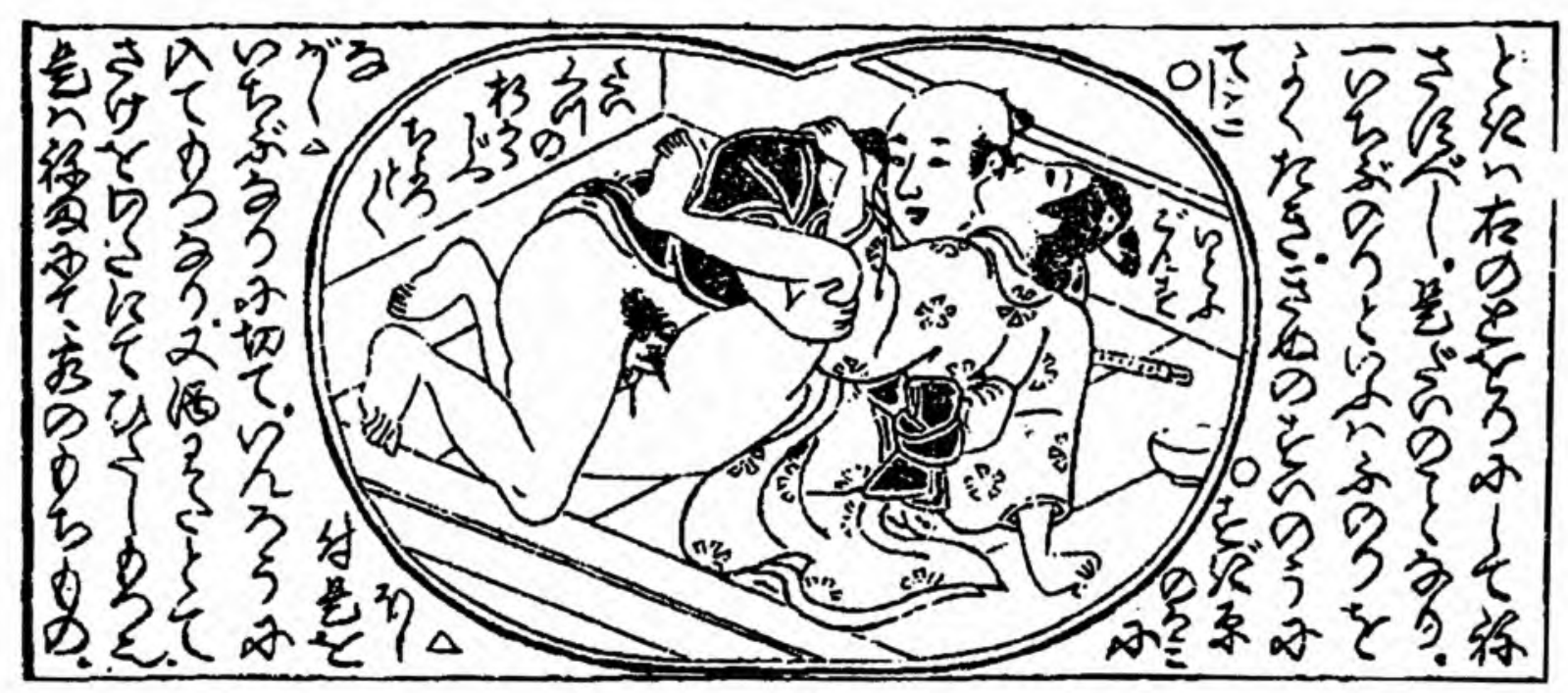

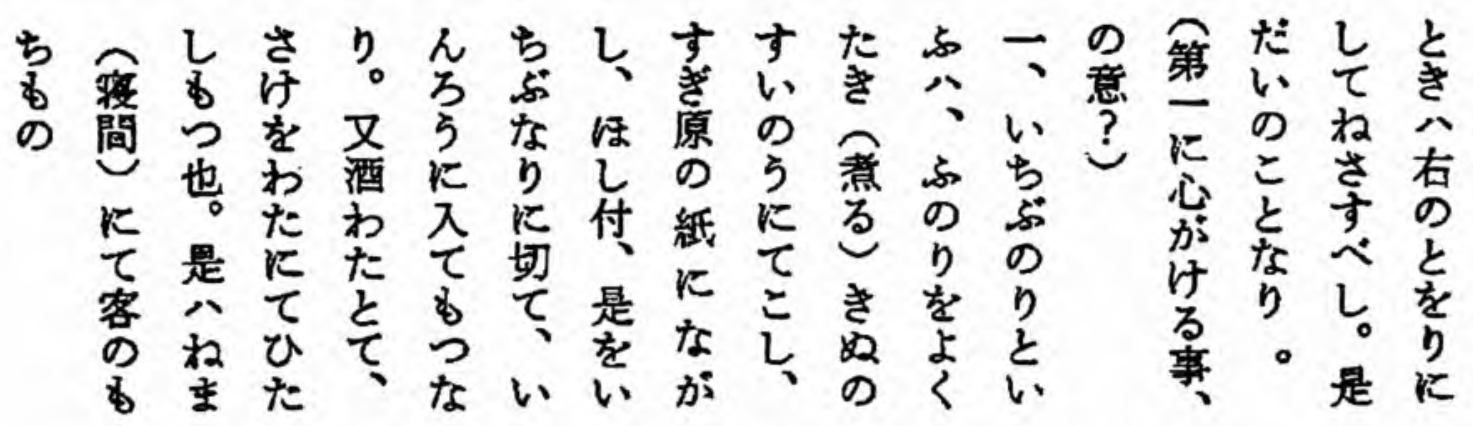

(...) deve-se fazê-la dormir da forma como se vê à direita. Isto é fundamental. (sentido de ser o ponto principal com que se cuidar?)

2. Quanto àquilo que se chama ichibu-nori [alga a 10\%]: deve-se cozinhar bem uma alga do mar [gloiopeltis], filtrar num saco de água de algodão, deixar deslizar através de papel de Sugiwara, deixar para secar e, quando estiver reduzido a $10 \%$, cortar e inseri-lo na caixa de medicamentos [inrô いんろう] para ter sempre consigo. Por outro lado, quanto ao algodãosaquê, trata-se de ter consigo um tecido embebido em saquê. Isto é recurso do cliente que ele leva ao quarto de dormir (...) 


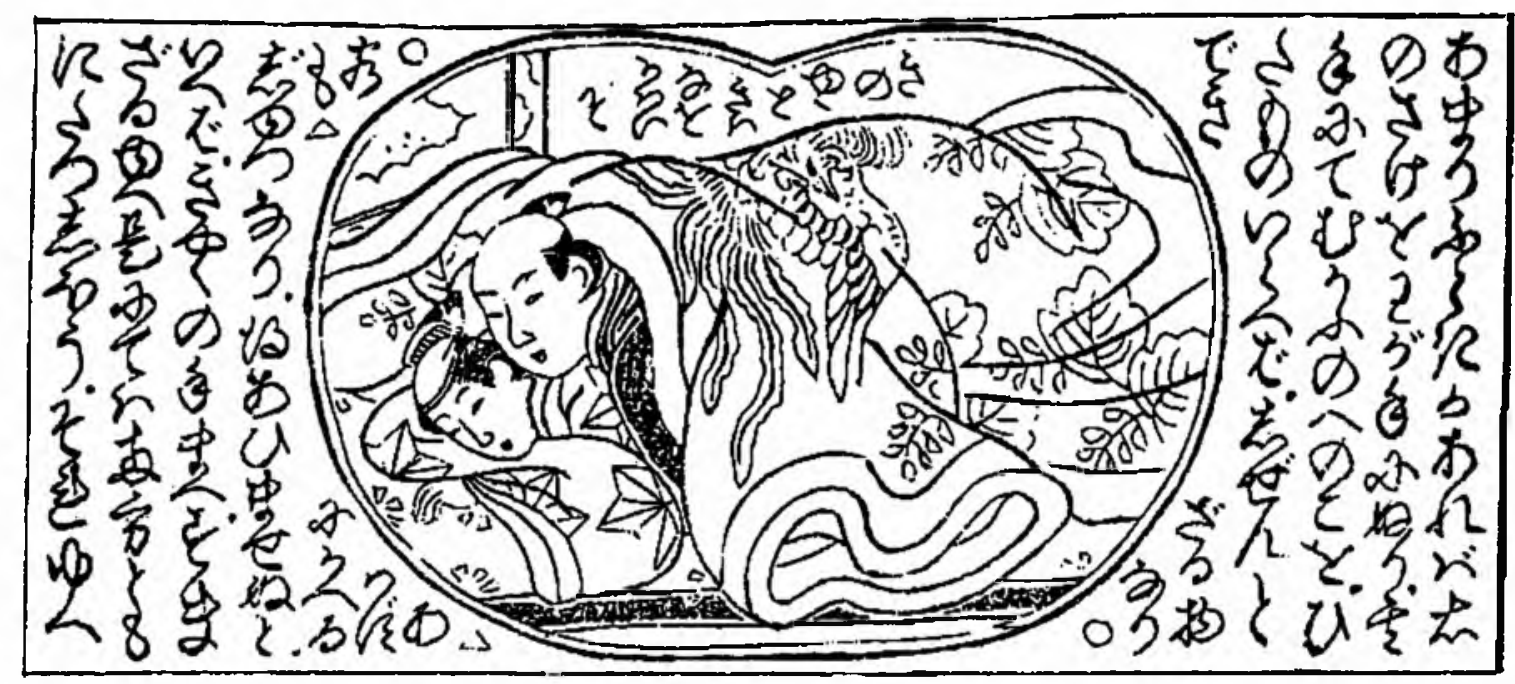

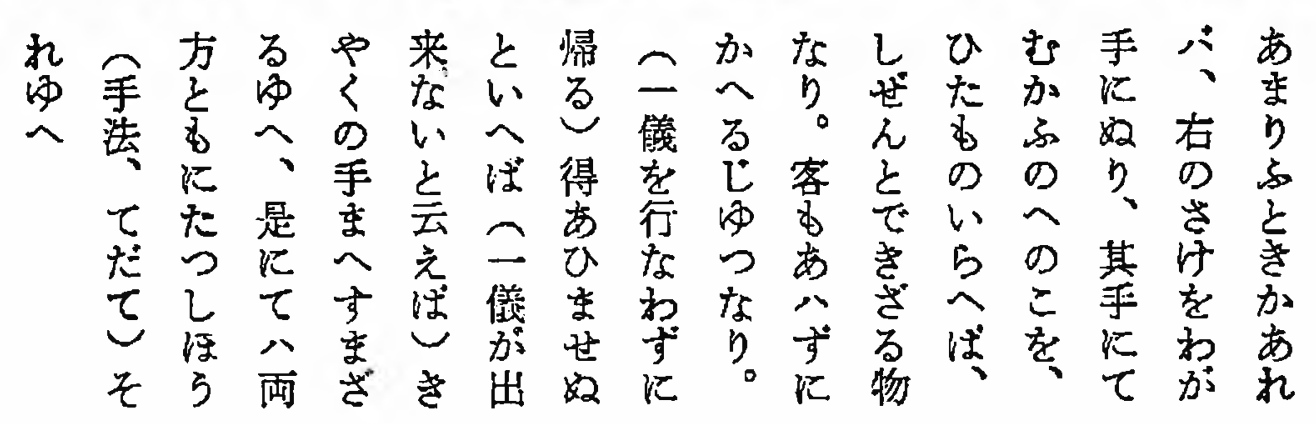

(...) mas se for muito grande, deve-se molhar sua própria mão no saquê da direita, e pegar para acariciar com esta mão o pinto do outro lado, e tudo vai ser possível de modo natural. Vai se tornar uma técnica para voltar sem encontrar-se com nenhum cliente (voltar sem manter nenhuma relação). Por falar em deixar esperar sem se encontrar (se não der para manter relações), além de fazer o cliente terminar com a mão, este é um método para ambos os participantes e além disso (...) 


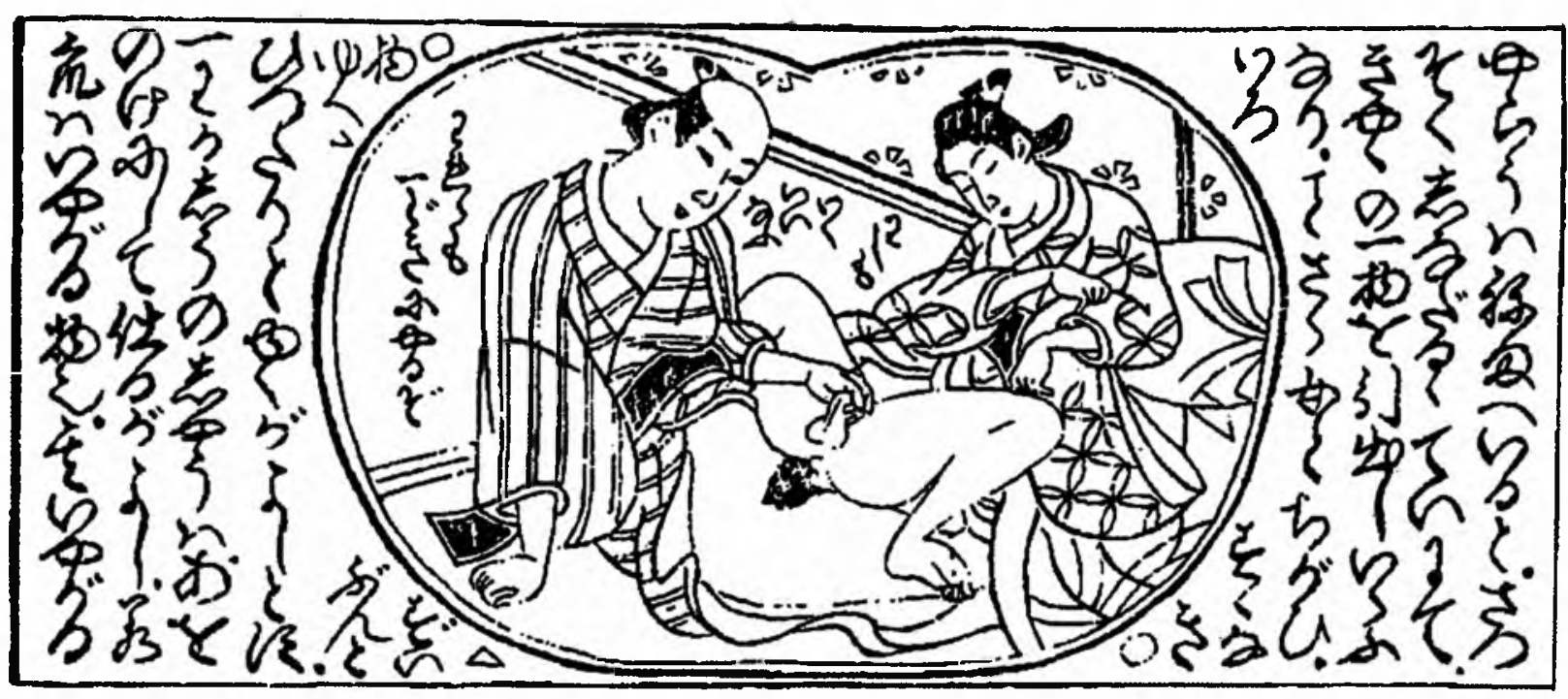

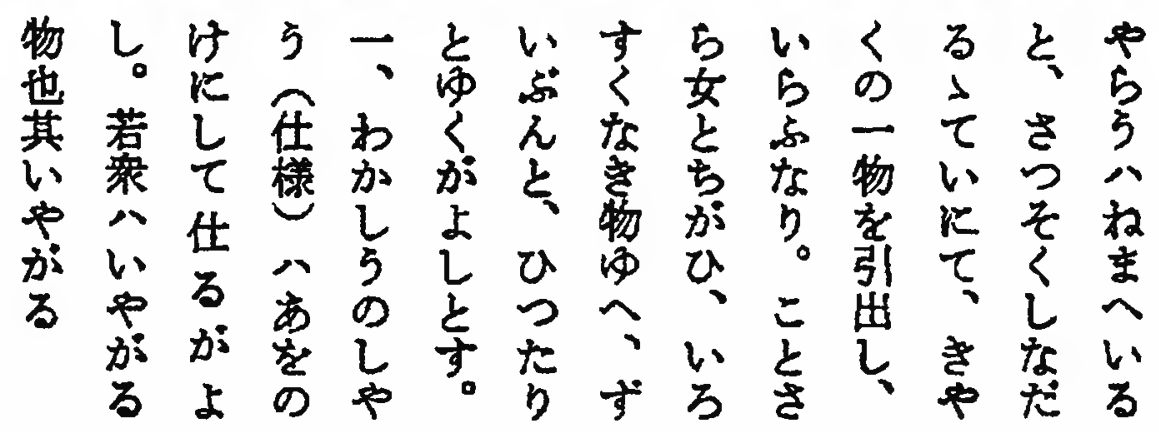

(...) quando o mais velho se encontra no quarto de dormir, o corpo logo se inclina para ele bem coquete e tira a propriedade [o pênis, ichimotsu 一物] do cliente em reconhecimento. É especialmente diferente de uma mulher, pois a esta lhe falta sensualidade, e é bom que seja muito, muito apertado.

3. o modo de fazer (preparar) um garoto, é bom que seja virado para cima. Um garoto desgosta mesmo e desgosta disso (...) 


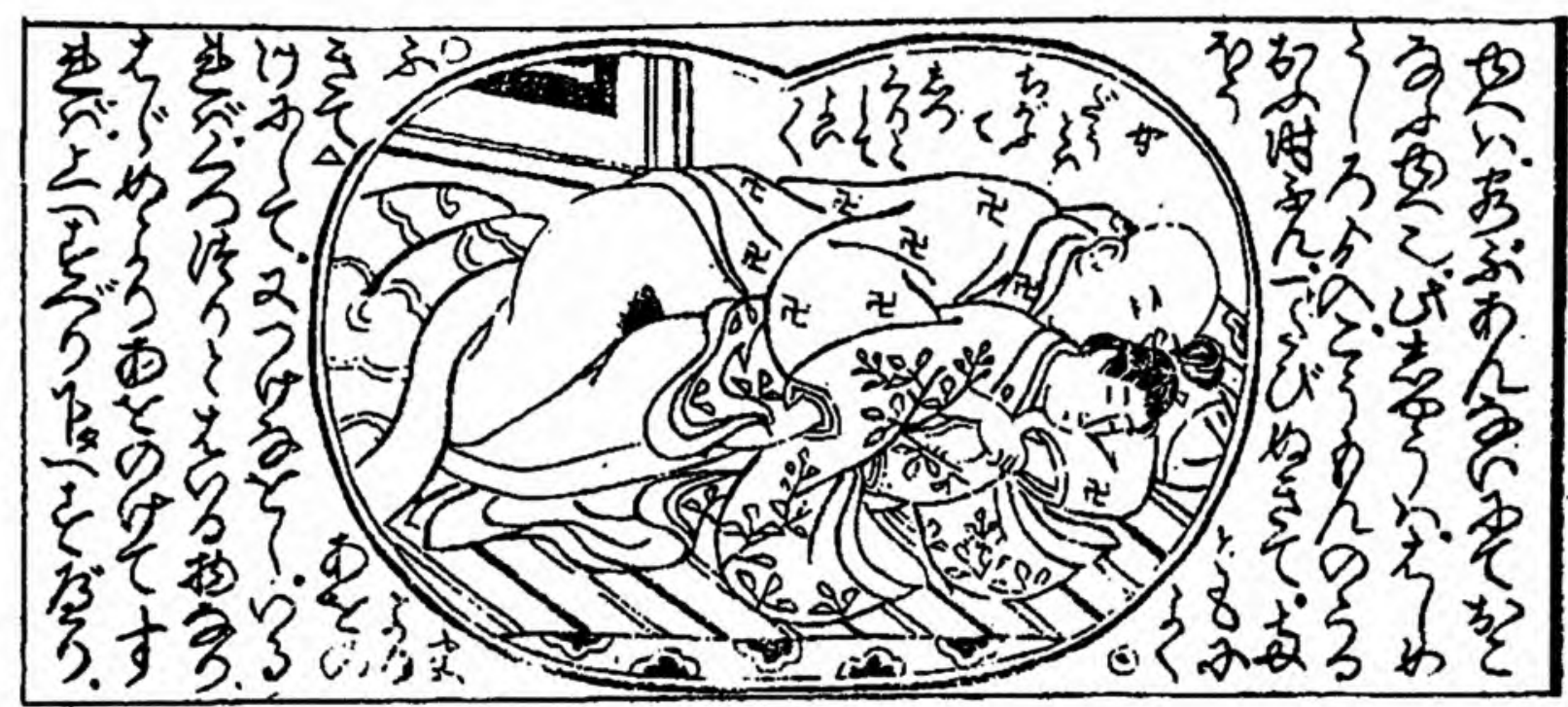

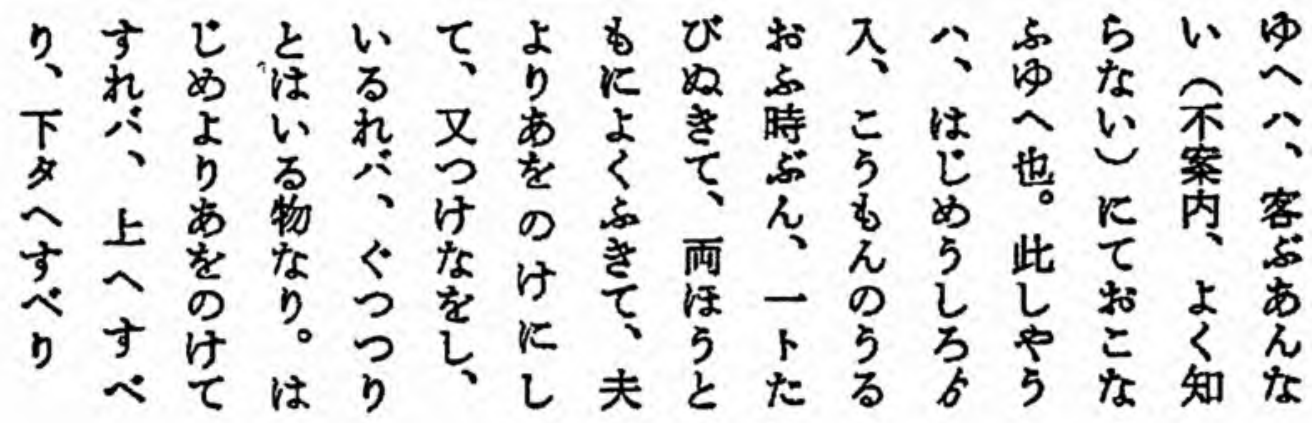

(...) porque mesmo não conhecendo bem o cliente, [sabe que] tem de fazer o guia (ou não fazer, não se sabe). Quanto a esse jovem, no começo entra-se por trás, na hora de devastar seu Portal Anal, deve-se tirar uma vez e limpar bem ambos os lados, o marido [o mais velho] deve fazê-lo virar-se para cima e de novo penetrar; se entrar, vai grudar de tão apertadinho. Se fizer desde o começo virado para cima, vai escorregar mais para cima, parecendo que escorrega para baixo (...)

Texto inserido:

"Nyodô e wa chigôte shikkuri to shite yoi yoi"

「女道えはちがふてしつくりとしてよいハィ」

"É diferente do caminho de mulheres, é bom, é muito bom como cabe perfeitamente!" 


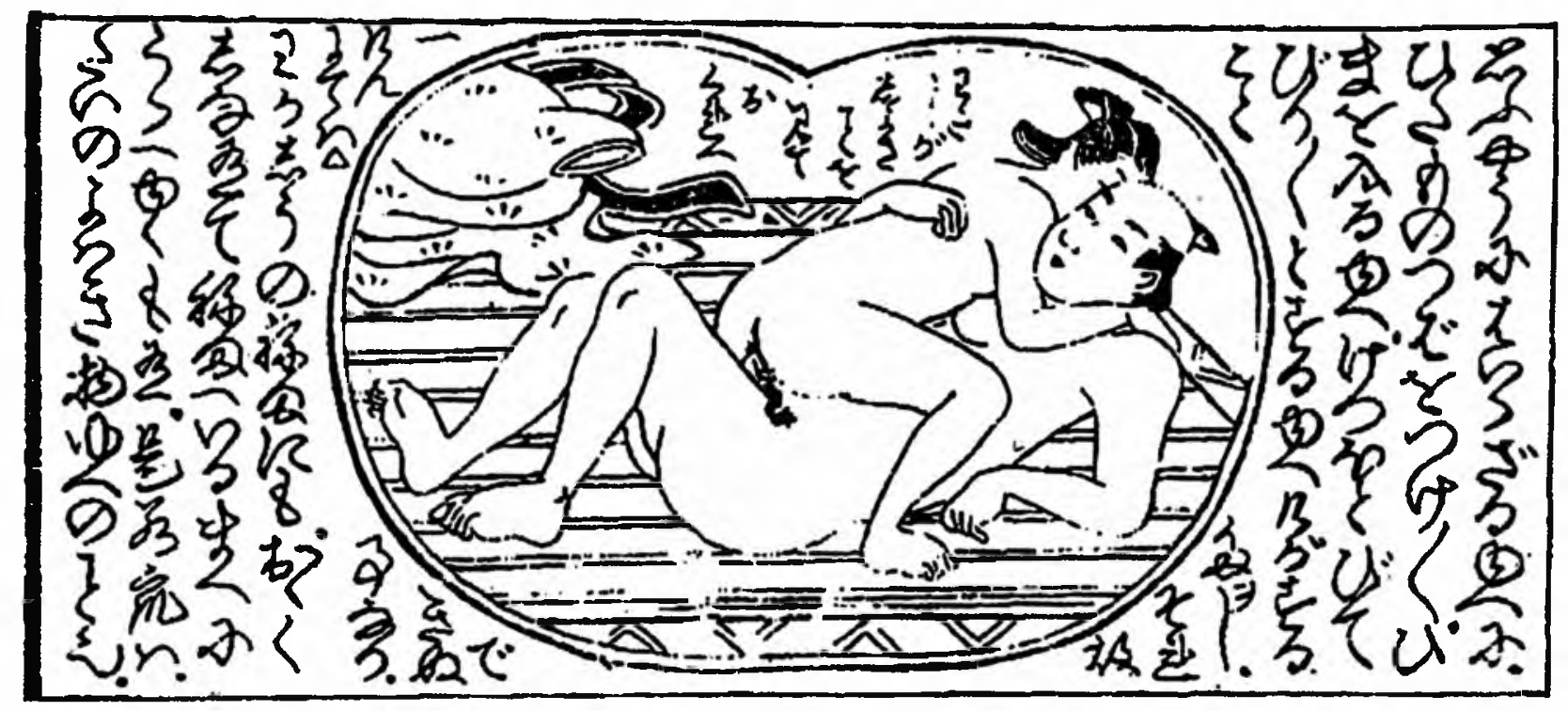

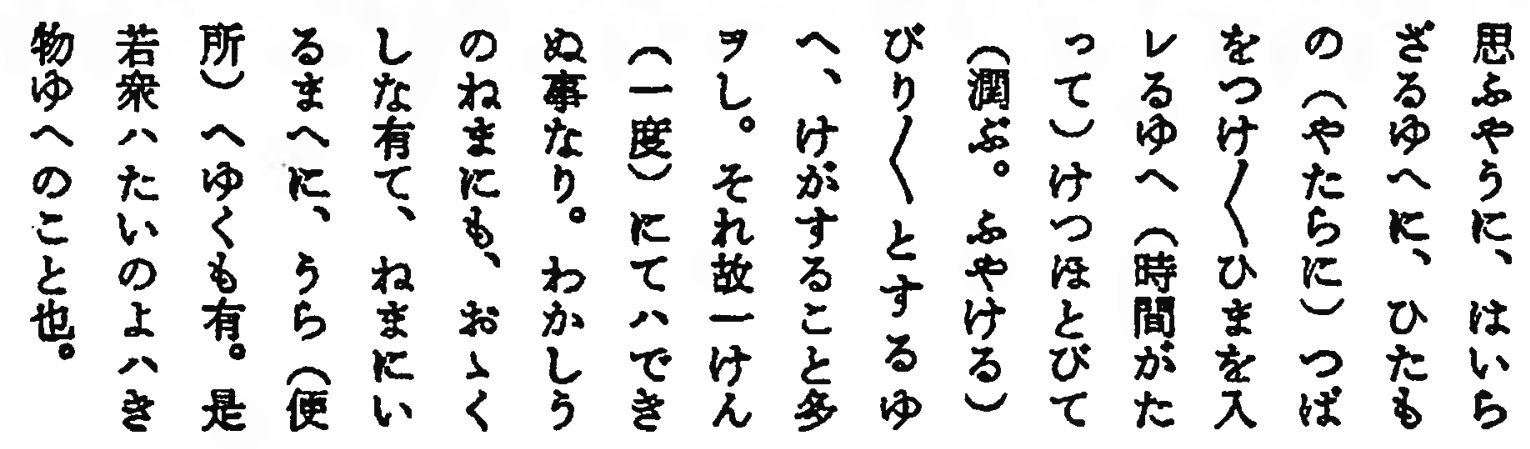

(...) e se não entrar, deve-se colocar grande quantidade (indiscriminada) de saliva, deixar um intervalo (de tempo), então o ânus vai inchar (ficar ensopado) e como vai se poder fazer até rasgar, são muito numerosos os casos de se machucarem. É por isso que é um ato que não se consegue fazer em uma vez (duma vez). Mesmo nos quartos de dormir dos garotos, deve ocorrer ensinamentos à mercadoria; antes de entrar em seus leitos, há vezes em que se vai ao aposento do fundo (banheiro). Nesse ponto é onde se encontra a fraqueza dos corpos dos garotos. 


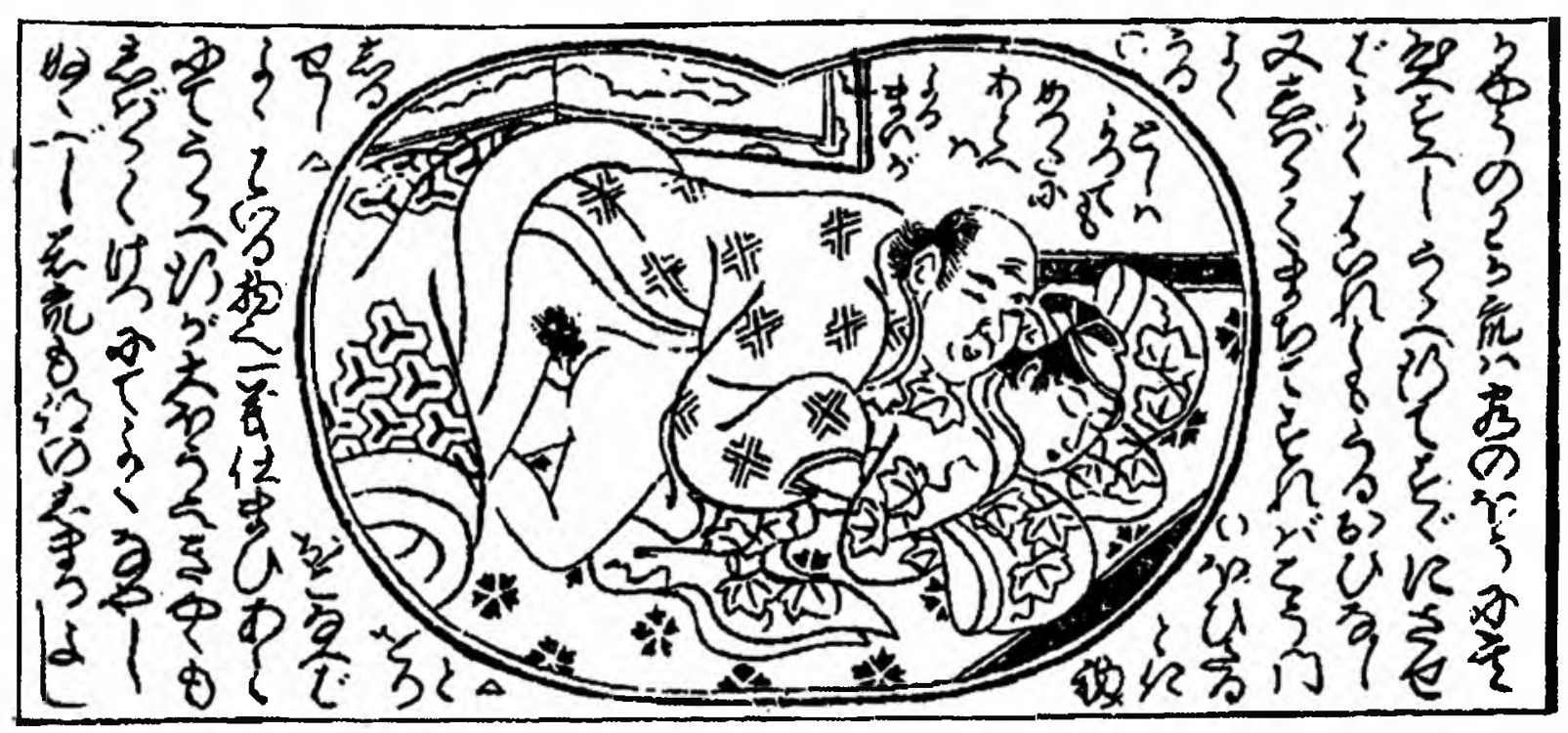

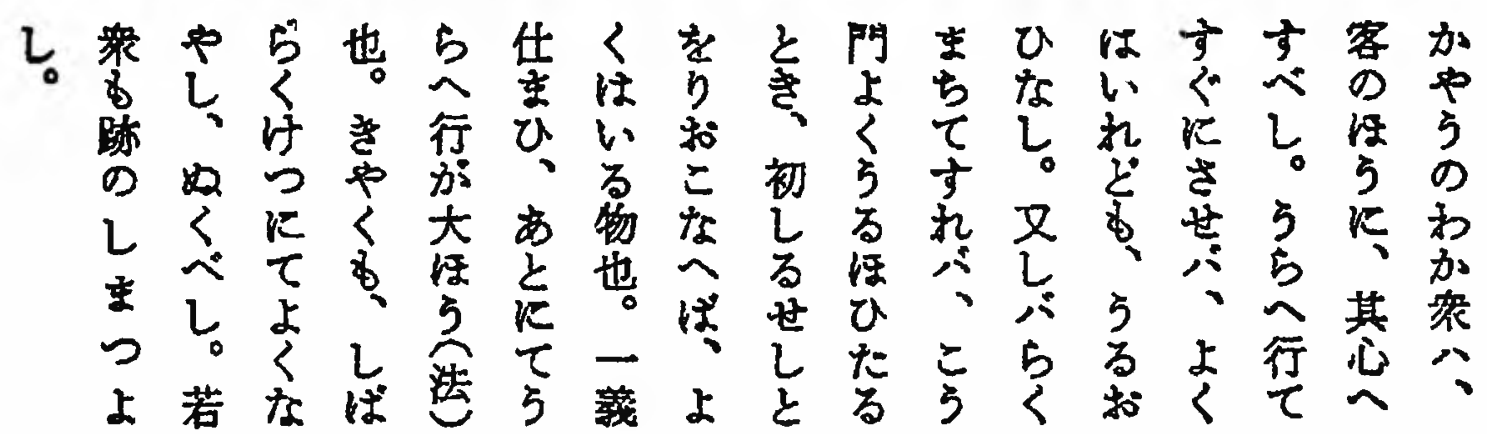

Os garotos desse tipo devem fazer de acordo com esse coração em relação aos clientes. Se depois de ir ao aposento do fundo e logo deixar fazer, além de entrar bem, não ficará encharcado. Ou então, se resolver esperar um pouco, na hora em que o Portal Anal estiver úmido, entrará bem fácil se realizar conforme se sabia do início. Terminando uma relação, depois a grande regra é ir ao aposento do fundo. O cliente também, deixa amolecer bem dentro do buraco e deve depois tirar. $\mathrm{O}$ garoto também é bom que disponha dos resíduos. 
Lendo-se a obra em seu todo, notamos que os textos altamente denotativos em volta das imagens não têm com elas uma relação direta, pois estas se concentram em mostrar cópulas de prováveis posições e personagens, com respectivas falas inseridas que não passam, em geral, de murmúrios amorosos. $O$ formato do balão em que as figurinhas se inserem lembra, muito a propósito, o Portal de Trás, numa poderosa informação subliminar... A versão visual que Hanasaki nos apresenta traz umas leves censuras nos órgãos sexuais, como se houvessem sido raspadas; Hayakawa ${ }^{4}$ apresenta quatro reproduções cujas linhas se encontram mais nítidas, mas em geral a leitura é bem realizável. Impreterivelmente compostas de um adulto e uma "criança", as variações se dão no cenário, nos motivos do vestuário, em expressões e gestos nunca repetidos e em expressões faciais do mais completo contentamento, especialmente por parte do "irmão mais velho"

Embora nada sentimental, o que nos resta da leitura de tais catecismos de aprendizado não se afasta muito dos comuns: uma ênfase na transmissão de ensinamentos através de um ponto de vista de cuidado paternalista de um superior (em idade, posição ou conhecimento) para novatos sôfregos por novidades.

\section{Bibliografia}

FUKUDA, Kazuhiko 福田和彦. Hihan Sôshihon-no Ukiyo-e 秘版 草紙本の浮世絵 (Publicações Secretas: Pinturas do Mundo Flutuante dos Livros Populares), 2 vols. Tóquio: Haga Shoten, 1982.

HANASAKI, Kazuo 花咲一男. Edo-no Kagema-jaya 江戸の陰間茶屋 (Casas de Chá de Garotos Prostitutos de Edo). Tóquio: Miki Shoten, 2002.

HASHIMOTO, Madalena [Madalena N Hashimoto Cordaro]. Pintura e Escritura do Mundo Flutuante: Hishikawa Moronobu e Ukiyo-e, Ihara Saikaku e Ukiyo-zôshi. São Paulo: Hedra, 2002.

HAYAKAWA, Monta 早川聞多. Ukiyo-e Shunga to Nanshoku 浮世絵春画の男色 (O Gênero Erótico da Pintura do Mundo Flutuante Ukiyo-e e o Amor por Garotos). Tóquio: Kawade, 1998.

HAYASHI, Yoshikazu 林美一. Ehon Kikô: Tôkaidô Gojûsan Tsugi 艶本紀行 東海道五十三 次 (Livro Erótico de Viagens: 53 Estações da Estrada Tôkaidô). Tóquio: Kawade, 1986.

LEUPP, Gary P. Male colors: The Construction of Homosexuality in Tokugawa Japan. Berkeley / Los Angeles / Londres: University of California Press, 1995.

SATÔ, Yôjin 佐藤要人. Edo Mizu-jaya Fûzoku-kô 江戸水茶屋風俗考 (Reflexões sobre os Usos-e-Costumes das Casas de Chá de Sexo de Edo). Tóquio: Miki Shoten, 1993.

SHIRAKURA, Yoshihiko 白倉敬彦 \& HAYAKAWA, Monta早川聞多. Himetaru Warai-no Sekai - Herushinki Shiritsu Bijutsukan / Ukiyo-e Shunga-ten 秘めたる笑いの世界/へ

4. In Ukiyo-e Shunga to Nanshoku, p. 64-65. 
ルシンキ市立美術館 浮世絵春画展 (O Universo Secreto do Riso-Museu Municipal de Helsinque / Exposição de Shunga Ukiyo-e). Tóquio: Yôsensha, 2003.

. org. Shunga Iro Moyô Hyakutai 春画色模様百態 (100 Modos e Modas Eróticas Shunga), vol. II. Tóquio: Taiyô, 2008.

SHIRAKURA, Yoshihiko 白倉敬彦, org. Shunga Edo-no Eshi Yonjû-hachi-nin 春画 江 戸の絵氏四十八人 (48 Pintores de Shunga de Edo). Tóquio: Taiyô, 2006.

SHUNROAN, Shujin 萝露庵主人. Edo-no Shikidô-Nanshoku-hen 江戸の色道＼cjkstart男色編(Os Caminhos do Sexo em Edo - Compilação do Amor por Garotos). Osaka: Habunkan, 1996.

Edo-no Shikidô - Shinansho-no Keifu 江戸の色道 指南書の系譜 (Os Caminhos do Sexo em Edo - Genealogia dos Livros de Instrução). Tóquio: Yôbunkan, 1998.

TANAKA, Yuko 田中優子 \& SHIRAKURA, Yoshihiko 白倉敬彦. Wakashu Gonomi - Edo Onna-no Iro to Koi 若衆好み 江戸女の色と恋 (A Fissura por Garotos - O Amor e o Sexo das Mulheres de Edo). Tóquio: Gakken, 2002.

TANOBE, Tomizô 田野辺富蔵. Isha Mitate Eisen “Makura Bunko”医者見立て 栄泉 「枕文庫」 (Posando de Médico: “A Biblioteca do Travesseiro" de Eisen). Tóquio: Kawade, 1966a.

\section{Dicionários especializados:}

KOMATSU, Keibun 小松奎文. Iro-no Jiten 色の辞典 (Dicionário do Erotismo). Tóquio: Bungeisha, 2000.

MAEDA, Osamu 前田勇. Edo-go Dai-Jiten 江戸語大辞典 (Grande Dicionário da Língua de Edo). Tóquio: Kôdansha, 1975, $1^{\text {a }}$ Ed.

SASAMA, Yoshihiko 笹間良彦. Kôshoku Engo Jiten 好色艶語辞典 (Dicionário de Termos Eróticos e Sexuais). Tóquio: Yûsankaku, 1989. 